\title{
Arthritis Induced by Proteoglycan Aggrecan G1 Domain in BALB/c Mice Evidence for T Cell Involvement and the Immunosuppressive Influence of Keratan Sulfate on Recognition of T and B Cell Epitopes
}

\author{
Yiping Zhang, ${ }^{*}$ Alexei Guerassimov, ${ }^{*}$ Jean-Yves Leroux, ${ }^{*}$ Annie Cartman, ${ }^{*}$ Carolyn Webber, ${ }^{*}$ Radomir Lalic, ${ }^{*}$ \\ Elisa de Miguel, ${ }^{\star}$ Lawrence C. Rosenberg, ${ }^{\ddagger}$ and A. Robin Poole ${ }^{\star}$ \\ *Joint Diseases Laboratory, Shriners Hospital for Children and Division of Surgical Research, Department of Surgery, McGill University, \\ Montreal, Quebec, H3G 1 A6 Canada; and ${ }^{\ddagger}$ Orthopedic Research Laboratories, Montefiore Medical Center, Bronx, New York 10467
}

\begin{abstract}
Our previous work showed that the proteoglycan aggrecan can induce erosive polyarthritis and spondylitis in BALB/c mice, and that the G1 domain of the proteoglycan aggrecan (G1) is the arthritogenic region. In this study, two T cell epitopes residing on G1 within residues 70-84 (peptide G5) and 150-169 (peptide G9) were identified using synthetic peptides and aggrecan-specific $T$ cell lines. Two G1-specific T cell hybridomas exclusively responded to peptide G5. When the G5-specific $T$ cell line was injected intraperitoneally into BALB/c mice, it induced acute inflammatory arthritis in joints, but only in those that had been injected with the epitope recognized by these $T$ cells. Furthermore, we also demonstrate that the keratan sulfate chain(s) (KS) on G1 possess immunosuppressive properties with respect to $T$ and $B$ cell epitope recognition. $T$ cell lines that recognize both G1 and peptide G5 show an increased response to G1 after KS is removed. Antibodies in hyperimmune sera of mice immunized with G1 show increased epitope recognition (quantitative and qualitative) after KS removal before immunization. These studies reveal that a $\mathrm{T}$ cell line specific to an epitope on the $\mathrm{G} 1$ domain of aggrecan, also recognizing a corresponding mouse G1 epitope, can induce arthritis by adoptive transfer and homing to the intraarticular epitope, thereby implicating $\mathrm{T}$ cells in arthritis development caused by immunity to the G1 domain of aggrecan. Moreover, the presence of KS on G1 can inhibit arthritis development by suppressing $\mathrm{T}$ and $\mathrm{B}$ cell epitope recognition. ( $J$. Clin. Invest. 1998. 101:1678-1686.) Key words: autoimmunity $\bullet$ autoimmune disease $\bullet$ peptide $\bullet$ antibody $\bullet$ recognition
\end{abstract}

\section{Introduction}

Patients with ankylosing spondylitis, juvenile, or adult rheumatoid arthritis exhibit $\mathrm{T}$ cell responses to the human cartilage proteoglycan $(\mathrm{PG})^{1}$ aggrecan $(1,2)$. Injecting fetal human cartilage aggrecan into $\mathrm{BALB} / \mathrm{c}$ mice produces a disease that has

Address correspondence to Dr. Yiping Zhang, Joint Diseases Laboratory, Shriners Hospital, 1529 Cedar Avenue, Montreal, Quebec, H3G 1A6, Canada. Phone: 514-849-5605; FAX: 514-842-5581; E-mail: yzhang@shriners.mcgill.ca

Received for publication 5 September 1997 and accepted in revised form 4 February 1998.

J. Clin. Invest.

(C) The American Society for Clinical Investigation, Inc. 0021-9738/98/04/1678/09 \$2.00

Volume 101, Number 8, April 1998, 1678-1686

http://www.jci.org features of both rheumatoid arthritis and ankylosing spondylitis $(3,4)$. We deduced that G1 contains critical regions responsible for arthritis and spondylitis, since both polyarthritis and spondylitis are observed after immunizing mice with human or bovine G1 domain of PG, but only after removing the glycosaminoglycan keratan sulfate (KS; reference 5). Passive transfer of PG-induced arthritis from arthritic to naive mice requires both $\mathrm{T}$ and $\mathrm{B}$ cells, as neither T cells alone (depletion of $\mathrm{B}$ cells) nor $\mathrm{B}$ cells alone (depletion of $\mathrm{T}$ cells) can adoptively transfer arthritis to syngeneic BALB/c mice (6). Arthritis development is directly related to humoral immunity to PG (4). Moreover, an in vivo $\mathrm{T}$ cell subset depletion study (7) also indicated that $\mathrm{CD}^{+} \mathrm{T}$ cells are required for the induction of arthritis. Therefore, an interaction between $\mathrm{T}$ and $\mathrm{B}$ cells must be involved in the pathogenesis of aggrecan or G1-induced arthritis. Humoral anti-PG antibody responses are significantly enhanced when chondroitin sulfate (CS) is removed from $P G$ $(3,4)$. In contrast, adult human PG, which has relatively more KS chains $(8,9)$, only occasionally induces arthritis, even after removal of CS (4). Removing the KS chains from the G1 markedly increases induction of the disease, probably in part by an enhancement of $\mathrm{T}$ cell responses via antigen uptake and processing in antigen-presenting cells $(5,10)$.

In this study, we identify two predominant $\mathrm{T}$ cell epitopes on G1 at residues 70-84 (G5) and 150-169 (G9). T cells specific to epitope G5 are able to induce arthritis when injected intraperitoneally into BALB/c mice. T cell lines specific to either G1 or peptide 70-84 show enhanced responses to KSdepleted G1 compared with native G1. We also show that in mice immunized with KS-depleted G1, the antibody response was considerably enhanced: the antibodies recognize more epitope-containing regions than in G1-immunized animals. Therefore, KS chains are able to suppress arthritis induction by diminishing both antigen-specific T and B cell responses.

\section{Methods}

Mice. Female 6-8-mo-old BALB/c retired breeder mice were obtained from Charles River Canada (St.-Constant, Quebec, Canada). Young female (6-7 wk) BALB/c mice (17-20 g) were used for induction of arthritis.

Culture medium and reagents. Medium for cell cultures was RPMI 1640 supplemented with $100 \mathrm{U} / \mathrm{ml}$ penicillin, $100 \mathrm{mg} / \mathrm{ml}$ streptomycin, $2 \mathrm{mM}$ L-glutamine, $0.1 \mathrm{mM}$ nonessential amino acids, $1 \mathrm{mM}$ sodium pyruvate (Gibco Laboratories, Grand Island, NY), and $50 \mathrm{mM} 2$-mercaptoethanol (Britsch Drug House, Poole, UK). The following reagents were used: FCS (Bockneck Ltd., Rexdale, ON Canada); cesium chloride (Kodak Chemical Co., Rochester, NY); guanidine hydro-

1. Abbreviations used in this paper: CS, chondroitin sulfate; KS, keratan sulfate; PG, proteoglycan. 
chloride, iodoacetamide, alcian blue, casein, $\mathrm{CNBr}$, diisopropyl fluorophosphate (DFP); PMSF, pepstatin A, and EDTA (Sigma Chemical Co., St. Louis, MO); protease-free chondroitin ABC lyase (EC4.2.2.4), keratanase (Pseudomonas EC2.1.103; Seikagaku America, Rockville, MD); CFA and IFA (Difco Laboratories Inc., Detroit, $\mathrm{MI})$; $\left[{ }^{3} \mathrm{H}\right]$ thymidine $(6.7 \mathrm{Ci} / \mathrm{mmol}$; ICN Biomedical Canada Ltd., Montrèal, Canada); Lympholyte M (Cedarlane Labs Ltd., Hornby, ON, Canada); aurodye, sodium iodide (Amersham Life Science Canada, Oakville, ON, Canada); paraformaldehyde (BDH), 3-(cyclohexylaminopropane sulfonic acid (USB Biologicals, Cleveland, $\mathrm{OH}$ ); and $\mathrm{N}$-tosyl, L-phenylalanine chloromethyl ketone-treated (Sigma Chemical Co.).

Antigens. G1 domain of bovine PG was purified as described previously by tryptic digestion of an aggregate preparation from calf articular cartilage and purification by gel chromatography $(10,11)$. It includes part of the interglobular domain between G1 and the G2 domain up to the first trypsin cleavage site (at residue arginine ${ }^{367}$ ). This fraction was dialyzed extensively against PBS, $0.45-\mu \mathrm{m}$ pore size filter-sterilized, and used in vitro.

Antibodies. The following B cell hybridomas were obtained from American Type Culture Collection (Rockville, MD) for preparing monoclonal antibodies: hamster IgG anti-mouse $\alpha \beta$ T cell receptor (H57-597), rat IgG2b anti-mouse CD4 (GK1.5), anti-CD8 (2.43), anti-I-A ${ }^{\mathrm{d}}+\mathrm{E}^{\mathrm{d}}$ (M5/114.15.2), and anti-HLA-B6 (SER8.B6). SER8.B6 was used as a control antibody for the rat IgG2b isotype since it does not interact with mouse lymphocytes. In addition, rat and mouse anti-TCR V $\beta 2$ (B20.6), V $\beta 4$ (RT4-10), V $\beta 6$ (44.22.1),

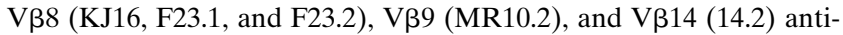
bodies were kindly donated by Dr. C. David (Mayo Clinic, Rochester, MN). FITC-conjugated rat anti-mouse IgG, mouse anti-rat IgG, and goat anti-hamster IgG (all from Jackson ImmunoResearch, West Grove, PA) were used as second antibodies for phenotype analysis.

Synthetic peptides. Peptides covering the full length of bovine aggrecan G1 domain (residues 1-367) were synthesized at a $0.25-\mathrm{mmol}$ scale using standard Fmoc (9-fluorenylmethoxycarbonyl) chemistry on a model 431A solid-phase peptide synthesizer (Applied Biosystems, Inc., Foster City, CA). The peptides were up to 27 amino acids long, and were overlapped by at least five amino acids (see Fig. 1). The crude peptides were purified by reverse-phase chromatography (Prep-10 Aquapore C8 column; Applied Biosystems, Inc.) using an acetonitrile gradient in $0.1 \%$ trifluoroacetic acid.

Digestion of antigens with glycosidases. PG or G1 was dissolved at $15 \mathrm{mg}$ (dry weight) $/ \mathrm{ml}$ and $250 \mu \mathrm{g}$ (dry weight) $/ \mathrm{ml}$, respectively, in $0.2 \mathrm{M}$ Tris- $\mathrm{HCl}$ buffer, $\mathrm{pH} 7.4$, containing $80 \mathrm{mM} \mathrm{NaCl}$ and the following protease inhibitors: $1 \mathrm{mM}$ EDTA, $1 \mathrm{mM}$ iodoacetamide, $5 \mu \mathrm{g} /$ $\mathrm{ml}$ pepstatin, and $2 \mathrm{mM}$ DFP or $1 \mathrm{mM}$ PMSF. The mixture was digested with either protease-free chondroitin $\mathrm{ABC}$ lyase $(0.2 \mathrm{U} / \mathrm{mg}$ protein) and/or by keratanase ( $2 \mathrm{U} / \mathrm{mg}$ protein) at $37^{\circ} \mathrm{C}$ for $20 \mathrm{~h}$ (12). The reaction was terminated by boiling the mixture for $5 \mathrm{~min}$. The digested samples were then dialyzed against water, dried on a Speed Vac (Savant, Hicksville, NY), and redissolved in sterile PBS at $1 \mathrm{mg} / \mathrm{ml}$. The solutions were $0.22-\mu \mathrm{m}$ pore size filter-sterilized and used in the assays. Reduction and alkylation of G1 domain were performed as described (9). All native G1 preparations used in the study of arthritis induction and in antigen presentation assays were boiled for $5 \mathrm{~min}$ regardless of keratanase treatment. Arthritis induction by the G1 domain is not a result of boiling alone, but also requires removal of KS (5).

Antigen-specific $T$ cell lines and clones and aggrecan-reactive $T$ cell hybridomas. Antigen- or peptide-specific T cell lines were established and characterized as described elsewhere (13) according to Ben-Nun et al. (14). In brief, mononuclear cells were from the lymph nodes of BALB/c mice immunized with whole antigen or peptide in CFA. These primed lymphocytes were cultured in RPMI 1640 medium plus $1 \%$ fresh syngeneic mouse serum in the presence of antigen or peptide. After $3 \mathrm{~d}$ in culture, the activated lymphoblasts were separated from the resting cells by gradient centrifugation. Cells at the gradient interface were collected, washed three times, and cultured in medium with $13 \%$ T cell growth factor (supernatant of ConA-activated mouse spleen cultures) and 10\% heat-inactivated FCS. The cells were restimulated with irradiated (4,000 rads) BALB/c spleen cells, as a source of antigen-presenting cells, and antigen after $10 \mathrm{~d}$. Restimulation and expansion cycles were repeated every 14-20 d.

The generation of two PG-reactive T cell hybridomas-TH5 and TH14-has been described elsewhere (10). In brief, spleen cells from arthritic mice were cyclically stimulated in vitro with PG and feeder cells. PG-reactive T cells were fused with BW5147 thymomas (kindly provided by Dr. P. Marrack, Denver, CO) to produce PG-reactive T cell hybridomas (15). These hybridomas were cloned, and TH5 and TH14, which react with aggrecan and bovine G1 (10), were used for further studies.

Phenotype and $T$ cell receptor usage of mouse autoreactive $T$ cell lines. $5 \times 10^{5}$ cells recovered from $\mathrm{T}$ cell lines with distinct specificity to aggrecan proteins or peptides were assessed by indirect immunofluorescence using a panel of anti-mouse poly or monoclonal antibodies and FITC-labeled anti-IgG antibodies (see Antibodies). Immunofluorescence was determined with a Cytoflorograph System 30-90 (FACScan $^{\mathrm{TM}}$; Becton Dickinson, San Jose, CA), and the data were analyzed using Lysis II software.

$T$ cell activation and proliferation assays. Antigen-specific $\mathrm{T}$ cell proliferation was assessed by coculturing antigen specific line cells

Table I. T Cell Phenotype and T Cell Receptor Usage of Aggrecan-specific T Cell Lines or Clones

\begin{tabular}{|c|c|c|c|c|c|c|c|c|c|}
\hline & \multirow[b]{2}{*}{ Specificity } & \multicolumn{2}{|c|}{$\mathrm{T}$ cell subsets } & \multicolumn{6}{|c|}{ TCR usage } \\
\hline & & $\mathrm{CD} 4$ & $\mathrm{CD} 8$ & $\operatorname{TCR} \alpha \beta$ & $\mathrm{V}_{\beta} 4$ & $\mathrm{~V}_{\beta} 6$ & $\mathrm{~V}_{\beta} 7$ & $\mathrm{~V}_{\beta} 8$ & $\mathrm{~V}_{\beta} 14$ \\
\hline \multicolumn{10}{|l|}{$\mathrm{T}$ cell line } \\
\hline MPG & PG & $84 \%$ & $9 \%$ & $95 \%$ & $10 \%$ & $<1 \%$ & $<1 \%$ & $57 \%$ & $<1 \%$ \\
\hline MG1 & G1 & $85 \%$ & $6 \%$ & $90 \%$ & $8 \%$ & $6 \%$ & $<1 \%$ & $39 \%$ & $<1 \%$ \\
\hline MG1-KS & G1KS & $77 \%$ & $5 \%$ & $92 \%$ & $7 \%$ & $4 \%$ & $<1 \%$ & $42 \%$ & $<1 \%$ \\
\hline MG5-9 & G5 \& G9 & $85 \%$ & $1 \%$ & $90 \%$ & $13 \%$ & $<1 \%$ & $<1 \%$ & $50 \%$ & $<1 \%$ \\
\hline MG5 & G5 & $86 \%$ & $3 \%$ & $93 \%$ & $16 \%$ & $3 \%$ & $<1 \%$ & $41 \%$ & $<1 \%$ \\
\hline \multicolumn{10}{|l|}{$\mathrm{T}$ cell clone } \\
\hline TH5 & G1 & $>95 \%$ & $<1 \%$ & $>95 \%$ & $>95 \%$ & $<1 \%$ & $<1 \%$ & $<1 \%$ & $<1 \%$ \\
\hline TH14 & G1 & $>95 \%$ & $<1 \%$ & $>95 \%$ & $<1 \%$ & $<1 \%$ & $<1 \%$ & $>95 \%$ & $<1 \%$ \\
\hline
\end{tabular}

T cell lines raised against chondroitin sulfate-depleted proteoglycan (MPG), aggrecan G1 domain (MG1), KS-depleted G1 protein (MG1-KS), G1 domain peptide G5 and G9 (MG5-9), G5 (MG5), or G1-specific T cell hybridoma clones (TH5 and TH14) were stained with monoclonal antibodies against mouse CD4, CD8, TCR $\alpha \beta$, TCR V $\beta 4, \mathrm{~V} \beta 6, \mathrm{~V} \beta 7, \mathrm{~V} \beta 8$, and V $\beta 14$. Stained cells were analyzed by flow cytometer and Lysis II software. The results are presented as percent of positive cells for each marker. 
(2-4 $\times 10^{4}$ cells/well), antigen-presenting cells $(4,000$ rads-irradiated syngeneic spleen cells, $2 \times 10^{5}$ cells/well), and whole antigen or peptide in optimal concentrations in $200 \mu \mathrm{l}$ of medium in round-bottomed microtiter plates (Nunc, Roskilde, Denmark). After $48 \mathrm{~h}$, the cultures were labeled with tritiated thymidine $(0.2 \mu \mathrm{Ci} /$ well $)$ and harvested 12-18 h later with a Skatron Multichannel Cellular Harvester. Radioactivity was quantified in a $\beta$-scintillation counter. For bovine G1-specific T cell hybridomas, $2 \times 10^{4}$ cells were cultured with $5 \times$ $10^{5}$ freshly isolated irradiated (4,000 rads) syngeneic spleen cells in quadruplicate with various antigens in a total volume of $200 \mu \mathrm{l} /$ well in 96-well flat-bottomed tissue culture plates (Falcon Laboratory, Franklin Lakes, $\mathrm{NJ}$ ) at $37^{\circ} \mathrm{C}$ for $24 \mathrm{~h}$ with $5 \% \mathrm{CO}_{2}$ and $95 \%$ air. The supernatants $(100 \mu \mathrm{l}$ per well) were harvested $24 \mathrm{~h}$ later and assayed for IL-2 in an IL-2-dependent mouse cytotoxic T cell line (CTLL-2; American Type Culture Collection) (16) by $\left[{ }^{3} \mathrm{H}\right]$ thymidine uptake as described before (10). All results were expressed either as mean $\mathrm{cpm} \pm \mathrm{SD}$ or as stimulation index (mean cpm with antigen/mean cpm with medium alone). The standard deviation of at least triplicate determinations was ordinarily $<15 \%$ of the mean.

ELISA assays for antibody and specificity. Arthritis was induced in BALB/c mice as described elsewhere (5). Blood samples were col-

Table II. Identification of T Cell Epitope(s) in G1 Using Synthetic Peptides

T cell line

MPG MPGn MG1 MG1KS MG5-9 MG5 TH5 TH14

\begin{tabular}{|c|c|c|c|c|c|c|c|c|}
\hline \multicolumn{9}{|l|}{ Antigen } \\
\hline PPD & $<2$ & 3.1 & $<2.7$ & $<2$ & $<2$ & $<2$ & ND & ND \\
\hline PG & 74.9 & 7.6 & 6.0 & ND & 4.6 & 8.1 & ND & ND \\
\hline G1 & 90.1 & 7.1 & 6.2 & 112 & 6.0 & 7.3 & 7.1 & 8.9 \\
\hline G1KS & 124.7 & 11.0 & 20.6 & 211 & 11.2 & 14.2 & 11.3 & ND \\
\hline \multicolumn{9}{|l|}{ Peptide } \\
\hline G0 (1-25) & $<2$ & $<2$ & $<2$ & $<2$ & $<2$ & $<2$ & $<2$ & $<2$ \\
\hline G1 (21-46) & $<2$ & $<2$ & $<2$ & $<2$ & $<2$ & $<2$ & $<2$ & $<2$ \\
\hline G3 (40-55) & $<2$ & 2.2 & $<2$ & $<2$ & $<2$ & $<2$ & $<2$ & $<2$ \\
\hline G4 (49-70) & $<2$ & $<2$ & $<2$ & $<2$ & $<2$ & $<2$ & $<2$ & $<2$ \\
\hline G5 (66-89) & 109 & 9.2 & 64.2 & 68.5 & 24.6 & 31 & 26.5 & 10.7 \\
\hline G6 (84-110) & $<2$ & $<2$ & $<2$ & $<2$ & $<2$ & $<2$ & $<2$ & $<2$ \\
\hline G7 (106-133) & $<2$ & $<2$ & $<2$ & $<2$ & $<2$ & $<2$ & $<2$ & $<2$ \\
\hline G8 (129-154) & $<2$ & 2.3 & $<2$ & $<2$ & $<2$ & $<2$ & $<2$ & $<2$ \\
\hline G9 (150-169) & 90 & 8.1 & 11.1 & 37.9 & 4.8 & $<2$ & 2.6 & $<2$ \\
\hline G10 (165-187) & $<2$ & $<2$ & $<2$ & $<2$ & $<2$ & $<2$ & $<2$ & $<2$ \\
\hline G11 (183-210) & 2.7 & $<2$ & $<2$ & $<2$ & $<2$ & $<2$ & $<2$ & $<2$ \\
\hline G12 (206-232) & $<2$ & $<2$ & $<2$ & $<2$ & $<2$ & $<2$ & $<2$ & $<2$ \\
\hline G13 (228-251) & $<2$ & $<2$ & $<2$ & $<2$ & $<2$ & $<2$ & $<2$ & $<2$ \\
\hline G14 (244-265) & $<2$ & 2.4 & $<2$ & $<2$ & $<2$ & $<2$ & $<2$ & $<2$ \\
\hline G15 (259-276) & $<2$ & $<2$ & $<2$ & $<2$ & $<2$ & $<2$ & $<2$ & $<2$ \\
\hline G16 (270-298) & $<2$ & $<2$ & 2.3 & $<2$ & $<2$ & $<2$ & $<2$ & $<2$ \\
\hline G17 (294-309) & $<2$ & $<2$ & $<2$ & 2.2 & $<2$ & $<2$ & $<2$ & $<2$ \\
\hline G18 (305-332) & $<2$ & $<2$ & $<2$ & $<2$ & $<2$ & $<2$ & $<2$ & $<2$ \\
\hline G19 (328-353) & 2.5 & $<2$ & $<2$ & $<2$ & $<2$ & $<2$ & $<2$ & $<2$ \\
\hline G20 (349-374) & $<2$ & $<2$ & $<2$ & $<2$ & $<2$ & $<2$ & $<2$ & $<2$ \\
\hline
\end{tabular}

$\mathrm{T}$ cell lines raised against chondroitin sulfate-depleted proteoglycan $(M P G)$, native PG $(M P G n)$, aggrecan G1 domain $(M G 1)$, KS-depleted G1 protein $(M G 1-K S)$, G1 domain peptide G5 and G9 (MG5-9), peptide G5 (MG5), or G1-specific T cell hybridoma clones (TH5 and TH14) were tested for proliferation in the presence of an optimal dose of bovine G1, G1KS, chondroitin sulfate-digested PG $(20 \mu \mathrm{g} / \mathrm{ml})$, or synthetic G1 peptides $(10 \mu \mathrm{g} / \mathrm{ml})$ as described in Methods. The results are expressed as stimulation index. lected by retroorbital bleeding as soon as clinical symptoms of arthritis appeared (between days 58 and 118). The sera were separated and used for a direct binding ELISA assay. In brief, G1 or synthetic peptides were diluted to $20 \mu \mathrm{g} / \mathrm{ml}$ in $0.1 \mathrm{M}$ carbonate buffer, $\mathrm{pH} 9.2$, and $50 \mu \mathrm{l}$ was added to each well $(1 \mu \mathrm{g} / \mathrm{ml})$ of Immulon-2 flat-bottomed microtiter plates (Dynatech Laboratories, Inc., Chantilly, VA). After $24 \mathrm{~h}$ at $4^{\circ} \mathrm{C}$, the plates were washed three times with PBS containing $0.1 \%$ (vol/vol) Tween 20 (PBS-Tween; Sigma Chemical Co.). Uncoated sites on the plastic surface were blocked with $150 \mu \mathrm{l} /$ well of $1 \%$ (wt/vol) casein (Fisher Scientific Co., Fairlawn, NJ) in PBS for $1 \mathrm{~h}$ at room temperature. The plates were washed three times with PBSTween. Then, $50 \mu \mathrm{l}$ of mouse serum (1:200 dilution) was added to individual wells. After $90 \mathrm{~min}$ at $37^{\circ} \mathrm{C}$, the plates were washed three times with PBS-Tween. Alkaline phosphatase-conjugated goat antimouse Ig diluted at 1:30,000 in 1\% casein PBS-Tween was added at $50 \mu \mathrm{l} /$ well. After $1 \mathrm{~h}$ at $37^{\circ} \mathrm{C}$, the plates were washed three times with PBS-Tween and once with distilled water. Finally, $50 \mu \mathrm{l}$ of freshly prepared alkaline phosphatase substrate (disodium p-nitrophenol phosphate; Sigma Chemical Co.) at $0.5 \mathrm{mg} / \mathrm{ml}$ in $8.9 \mathrm{mM}$ diethanolamine, $0.25 \mathrm{mM} \mathrm{MgCl}_{2}, \mathrm{pH}$ 9.8, was added to each well for 20-30 min at $37^{\circ} \mathrm{C}$. The absorbances were measured at $405 \mathrm{~nm}$ on a plate reader (ELx 808; Bio-Tek Instruments, Inc., Winooski, VT).

Identification of arthritogenic $T$ cell epitope of $G 1$ in $B A L B / c$ mice. $1 \mathrm{ml}$ of serum-free medium with or without $1 \times 10^{7}$ peptide G5-specific $T$ cells (MG5) were injected intraperitoneally into $\mathrm{BALB} / \mathrm{c}$ mice on day $0.1 \mathrm{~h}$ later, the left knee was injected intraarticularly with peptide G5 (10 $\mu \mathrm{g}$ in $10 \mu \mathrm{l}$ serum-free medium), whereas the right knee joint was injected with an equal amount of unrelated peptide (peptide Y15, NDGAQIAKVGQIFAAWKLLGYDRCD of bovine link protein) or medium alone. The mice were monitored for joint swelling on a daily basis. On day 6 or 7 , usually the peak of the joint swelling, the mice were killed and the joints were removed and fixed in $10 \%$ buffered formalin for $2 \mathrm{~d}$, decalcified, sectioned, and stained with hematoxylin and eosin, examined microscopically, and scored as: +++ , considerable mononuclear cell infiltration in synovium and capsule with erosive bone destruction; ++ , considerable mononuclear cell infiltration in synovium and capsule without erosions; + , moderate mononuclear cell infiltration in synovium and capsule; \pm , trace amounts of mononuclear cell infiltration in synovium and capsule; -, normal.

Table III. The Cross-reactivity Among Human, Bovine, Mouse, and Rat Aggrecan G1 Domain T Cell Epitopes and Further Definition of the T Cell Epitope to Residues 70-84

\begin{tabular}{lccc}
\hline & \multicolumn{3}{c}{ T cell line } \\
\cline { 2 - 4 } Antigen/peptide & MG1 & MG1KS & MG5 \\
\hline Medium & $82 \pm 16$ & $395 \pm 41$ & $137 \pm 27$ \\
Con A & $58508 \pm 5501$ & $85944 \pm 1773$ & $23807 \pm 3038$ \\
G5 (66-89) & $5663 \pm 462$ & $9700 \pm 698$ & $5373 \pm 334$ \\
G5.15 (70-84) & $4235 \pm 578$ & $7873 \pm 933$ & $4009 \pm 631$ \\
G5H (66-89) & $4078 \pm 511$ & $8578 \pm 886$ & $5538 \pm 493$ \\
G5M (66-89) & $2072 \pm 199$ & $2063 \pm 265$ & $1621 \pm 180$ \\
G5R (66-89) & $2072 \pm 199$ & $2063 \pm 265$ & $1621 \pm 180$ \\
G2 (21-46) & $119 \pm 34$ & $496 \pm 76$ & $222 \pm 36$
\end{tabular}

$4 \times 10^{4} \mathrm{G} 1$ peptide-specific T cells (MG1, MG1KS, and MG5) were cocultured without or with synthetic peptide G2, G5, G5.15, GH5, G5M, G5R $(10 \mu \mathrm{g} / \mathrm{ml})$, or con A $(5 \mu \mathrm{g} / \mathrm{ml})$ in the presence of antigen-presenting cells. Peptide G2 (21-46) is a T cell-independent peptide, and served as a control peptide in this experiment. The $\mathrm{T}$ cell response was measured by a standard $\left[{ }^{3} \mathrm{H}\right]$ thymidine incorporation assay, and the results were expressed as mean cpm of triplicates \pm SD. 


\section{Results}

Identification of predominant $T$ cell epitope(s) of $G 1$ in $B A L B / c$ mice. In previous animal studies, we have shown that aggrecan, more specifically the G1 domain, is able to induce an RAlike arthritis in BALB/c mice (5). In this study, T cell lines $(n=$ 7) specific to bovine $\mathrm{PG}, \mathrm{G} 1$, or distinct regions of $\mathrm{G} 1$ were generated from the draining lymph nodes of antigen/CFAprimed BALB/c mice. After $1.5 \mathrm{mo}$ in culture with repeated stimulation with specific antigen and propagation in IL-2-conditioned medium, all these autoreactive $\mathrm{T}$ cell lines were found to: $(a)$ be $\mathrm{CD}^{+}$and $\mathrm{CD}^{-} \mathrm{T}$ lymphocytes (Table I); $(b)$ be absolutely specific for the immunizing antigen (Table II); (c) be poorly reactive or nonreactive to purified protein derivative of tuberculin $(P P D)$ (Table II), an important $\mathrm{T}$ cell immunogen in FCA; and $(d)$ use the $\alpha \beta$ T cell receptor (TCR) with preferential of TCR V $\beta 8$ (39-57\%) or V $\beta 4(7-13 \%)$ usage over other TCR V $\beta$ elements (Table I). TCR V $\beta 8$ usage is frequently found in autoimmunity $(17,18)$.

T cell lines specific for G1, G1 depleted of KS (G1-KS), or G1 peptide were isolated. When cultured with the synthetic, overlapping G1 peptides in the presence of syngeneic APCs,

Table IV. The Profile of Synthetic Peptides of Bovine Proteoglycan Aggrecan G1 Domain Used in This Study

\begin{tabular}{lcl}
\hline Peptide code & Residues & \multicolumn{1}{c}{ Sequences } \\
\hline G0 & $1-25$ & VEVSEPDNSLSVSLREPSPLRVLLG \\
G2 & $21-46$ & RVLLGTSLTIPCYFIDPMHPVTTAPS \\
G3 & $40-55$ & TTAPSTAPLAPRIK \\
G4 & $49-70$ & YPLAPRIKWSRVSKEKEVVLLVA \\
G5 & $66-89$ & VLLVATEGRVRVNSAYQDKVSLPN \\
G5-H & $66-89$ & VLLVATEGRVRVNSAYQDKVTLPNYP \\
G5-M & $66-89$ & VLLVATEGQVRVNSIYQDKVSLPN \\
G5-R & $66-89$ & VLLVATEGQVRVNSIYQDKVSLPN \\
G5.15 & $70-84$ & ATEGRVRVNAYQDK \\
G6 & $84-110$ & KVTLPNYPAIPSDATLEIQNMRSNDSG \\
G7 & $106-133$ & SNDSGIYRCEVMHGIESGQATLEVVVKG \\
G8 & $129-154$ & VVVKGIVFHYRAISTRYTLDFDRAQRG \\
G9 & $150-169$ & DRAQRACLQNSAIIATPEQL \\
G10 & $165-187$ & TPEQLQAAYEDGFHQCDAGWLAD \\
G11 & $183-210$ & GWLADQTVRYPIHTPREGCYGDKDEFPG \\
G12 & $206-232$ & DEFPGVRTYGIRDTNETYDVYCFAEEM \\
G13 & $228-251$ & FAEEMEGEVFYATSPEKFTFQEAAG \\
G14 & $244-265$ & KFTFQEAANECRRLGARLATTG \\
G15 & $259-276$ & ARLATTGQLYLAWQGGMD \\
G16 & $270-298$ & AWQAGMDMCSAGWLADRSVRYPISKARPNGC \\
G17 & $294-309$ & KARPNCGGNLLGVRV \\
G18 & $305-332$ & GVRTVYVHANQTGYPDPSSRYDAICYTG \\
G19 & $328-353$ & ICYTGEDFVDIPENFFGVGGEEDITVG \\
G20 & $349-374$ & EDITVQTVTWPDMELPLPRNITEGEAG \\
& & \\
\hline
\end{tabular}

The peptide G5-M, G5-R, G5-H represents human, mouse, and rat G1 sequence at residue $66-89$, respectively. Other peptides (G0 to G21) are from the bovine $\mathrm{G} 1$ sequence. The sequences of the bovine $\mathrm{G} 1$ domain are based on reference 32, and P.J. Neame and L.C. Rosenberg unpublished data. The human, mouse, and rat aggrecan G1 protein sequences are based on references 19,21, and 22, respectively. The light font shows added amino acids which are not part of the G1 sequence. The underlined residues show the differences from the bovine G1 domain sequence. they responded strongly to two peptides (G5, G9) representing distinct regions, namely residues 66-89 and 150-169, respectively (see Table II). By contrast, the remaining peptides initiated either a very weak response or no response at all. A peptide 66-89-specific $\mathrm{T}$ cell line (MG5) was also generated in vitro from $\mathrm{BALB} / \mathrm{c}$ mice immunized with this peptide (G5), and, as expected, responded to PG, G1, and G1-KS, but not to unrelated proteins or peptides (Table II). Our data indicate that peptides G5 and G9 contain dominant $\mathrm{T}$ cell epitope sequences, and that both epitopes can be processed naturally and be presented by APCs. The T cell epitope in bovine G1 66-89 was mapped more precisely to residues 70-84 (peptide G5.15), since T cell lines specific to G1 (MG1), G1KS (MG1KS), or peptide G5 (MG5) all responded equally well to peptide G5 or G5.15 (Table III).

We also found that two previously reported $\mathrm{T}$ cell hybridomas (TH5 and TH14; references 5 and 10), generated from arthritic BALB/c mice injected with bovine $\mathrm{G} 1$, recognize epitopes within residues 70-84 of peptide G5 (Table II). Coincidentally, TH5 uses TCR V $\beta 8$ and TH5 uses V $\beta 4$. Both V $\beta 8$ and $\mathrm{V} \beta 4$ are frequently used by aggrecan-reactive $\mathrm{T}$ cell lines (Table I). These data showed that peptides 70-84 and 150-169 represent predominant $\mathrm{T}$ cell epitopes not only in CS-depleted PG and native G1, but also in KS-depleted G1. Although the response to peptide 150-169 was somehow less than to peptide $70-84$, it is always detectable in the cells specific for PG or G1 (Table II).

Cross-reactivity between bovine peptide G5 and the corresponding region of mouse G1. Synthetic peptide G5 (bovine G1 residues 66-89) is located in the conserved region of G1. In the human sequence, serine residue 86 is replaced by a threonine. This amino acid substitution has no effect on the antigenspecific $\mathrm{T}$ cell response (Table III), indicating that bovine and human aggrecan G1 share the same $\mathrm{T}$ cell epitope. In the mouse and rat, residues 70-84 are identical to each other but, when compared to the cow, amino acid substitution occurs

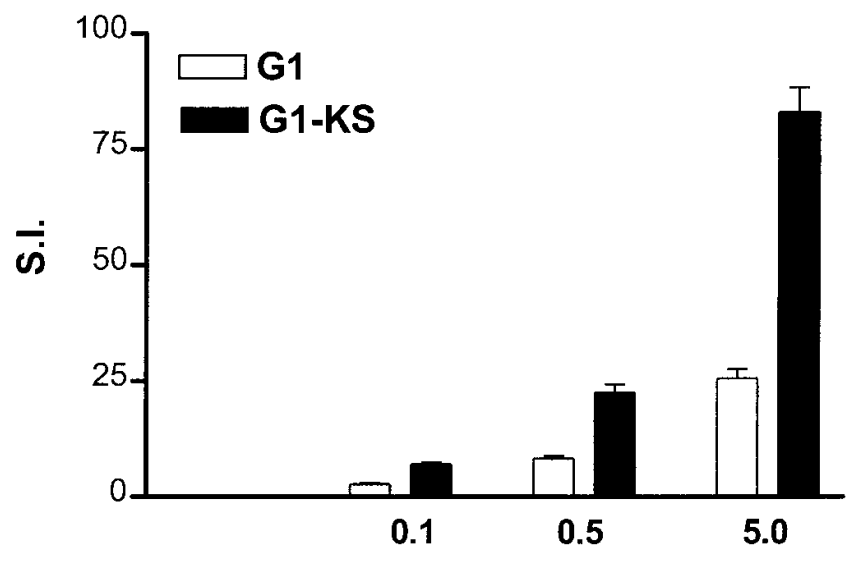

\section{Antigen $(\mu \mathrm{M})$}

Figure 1. Removal of KS chains enhances the antigen-specific T cell response. $4 \times 10^{4} \mathrm{G} 5$ peptide- specific (MG5) T cells were cocultured with different doses of aggrecan G1 (open bar) or KS-depleted G1 protein (black bar) in the presence of $2 \times 10^{5}$ irradiated (4,000 rads) $\mathrm{BALB} / \mathrm{c}$ spleen cells as antigen-presenting cells, and the T cell response was measured by a standard $\left[{ }^{3} \mathrm{H}\right]$ thymidine incorporation assay. The results are expressed as mean stimulation index \pm SD. 
twice between residues $70-84$ at residue 74 (glutamine instead of arginine) and 80 (isoleucine instead of alanine; Table IV). Antigen-specific T cell responses are still detectable, however, to the mouse/rat peptide $(\mathrm{G} 5 \mathrm{M} / \mathrm{R})$. All three $\mathrm{T}$ cell lines (MG1, MG1KS, and MG5) specific to bovine G1 show considerable cross-reactivity to the corresponding mouse sequence (Table III), but not to the G1 domain peptide 21-46 (G2; Table III), even though the peptide $21-46$ has been shown to be the predominant $\mathrm{T}$ cell epitope of aggrecan $\mathrm{G} 1$ domain in Lewis rat (Y. Zhang and A.R. Poole, unpublished data).

Removing the $K S$ chains from $G 1$ enhances $T$ cell reactivity. The reactivity of aggrecan-specific $\mathrm{T}$ cell lines and $\mathrm{T}$ cell hybridomas was studied before and after treatment of G1 with keratanase, which cleaves the KS chains. Significant enhance-
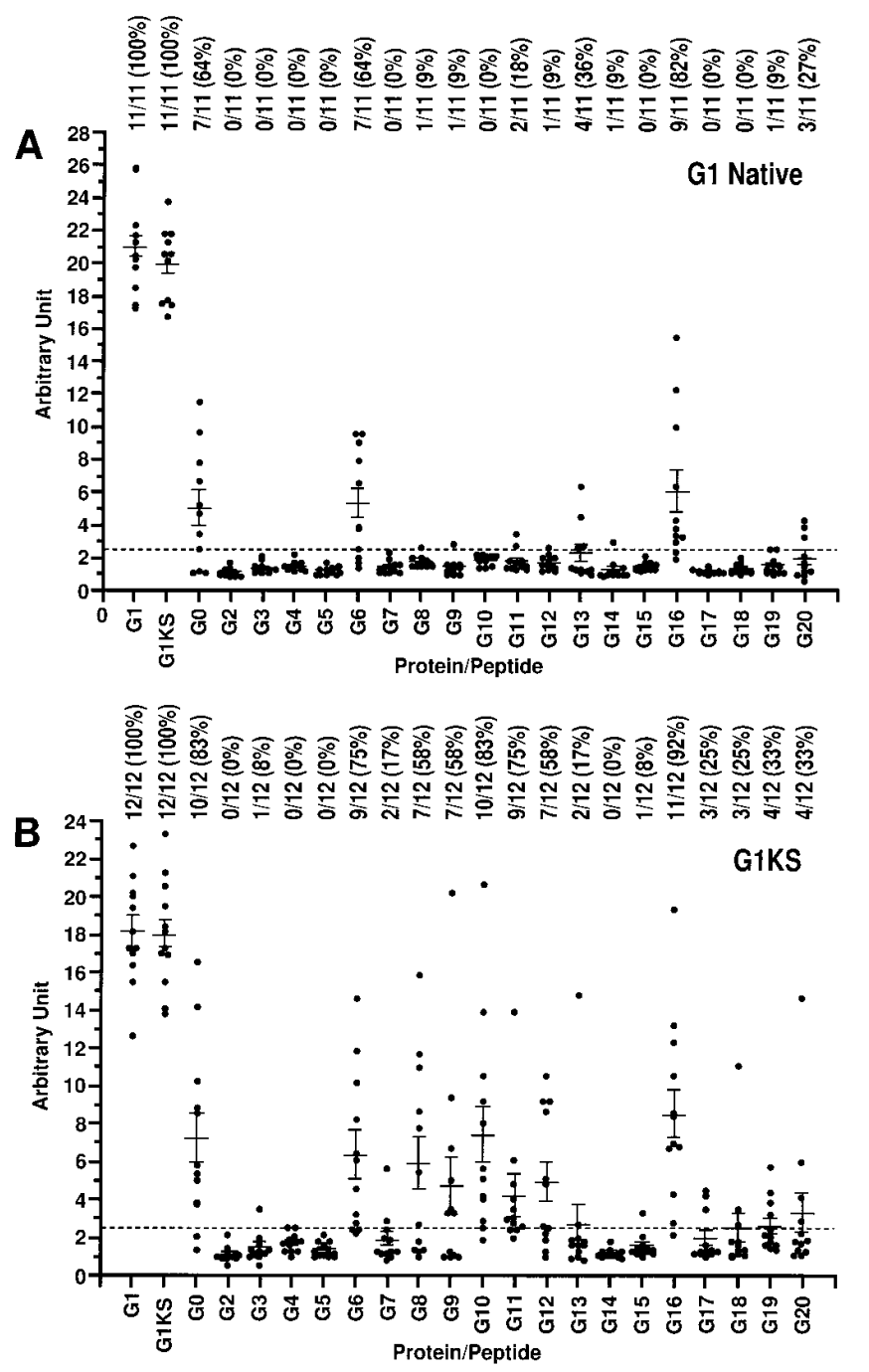

Figure 2. The presence of KS on aggrecan G1 domain inhibits the humoral antibody response to G1. $(A)$ Sera isolated from BALB/c mice on day 85 after hyperimmunization with native $\mathrm{G} 1(n=11)$ or $(B)$ KS-depleted G1 $(G 1-K S ; n=12)$ were assayed for their reactivity to bovine G1, G1KS, or G1 peptides. The background (casein) were all under 0.9 at the range from 0.57 to 0.88 . The arbitrary unit was calculated as the experimental OD value divided by background (casein) OD value. Units exceeding 2.5 (broken line) was recorded as a positive reaction. The proportion of positive of total, the positive percentage and mean \pm SD are also shown. ment of $\mathrm{T}$ cell reactivity is seen after depletion of KS when compared with native G1 (Table II). Similar results were obtained in at least two repeated experiments. We also demonstrate that exposure of the T cell epitope in residues 70-84 accounts for the enhancement. The $\mathrm{T}$ cell line MG5, which is specific for peptide 70-84, showed an enhanced response (two to threefold) vs. G1 native to G1KS (Fig. 1) at low (0.1 $\mu \mathrm{M})$ as well as high $(5 \mu \mathrm{M})$ antigen doses (Fig. 1).

The majority of linear B cell epitope(s) are masked by keratan sulfate. We recently discovered that bovine G1, after depletion of KS chains, is able to induce arthritis in a high proportion of BALB/c mice (5). Since both $\mathrm{T}$ and $\mathrm{B}$ cells are involved in the pathogenesis of G1-induced arthritis $(6,7)$, we assume that, in addition to enhancing the $\mathrm{T}$ cell response, depletion of KS may also enhance B cell immunity. Therefore, it was important to identify arthritis-related B cell epitope(s) of G1. Sera, collected at the day of onset of arthritis (day 58-118) from BALB/c mice immunized with either G1 or G1 treated with keratanase, were assayed by ELISA against a set of synthetic peptides covering the full length of bovine G1 and overlapping by at least five amino acids (Fig. 1). Three immunogenic regions located at residues 1-25, 84-110, and 270-298 (Fig. $2 A$ ) were defined by sera of mice immunized with native G1, which covers $19.3 \%$ of the G1 domain. However, sera from mice immunized with keratanase-treated G1 show an enhanced antibody response and recognize additional regions of G1 within residues 129-232 and 305-374 in an area covering $46 \%$ of G1(Fig. 2 B). These results suggest that the KS chains in $\mathrm{G} 1$ mask two broad regions, and prevent them from inducing antibodies. We conclude that removing the KS chains not only enhances autoreactive $\mathrm{T}$ cell reactivity to $\mathrm{G} 1$, but also enhances recognition of additional B cell epitopes on aggrecan $\mathrm{G} 1$.

Arthritis induced by peptide G5-specific $T$ lymphocytes. MG5 is a T cell line (CD4-positive) that is specific for a T cell epitope in the aggrecan G1 domain (peptide G5), and ex-

Table V. Induction of Arthritis by Peptide G5 (70-84)-specific $T$ Cell Line (MG5) in BALB/c Mice

\begin{tabular}{|c|c|c|c|c|c|c|c|}
\hline \multirow[b]{2}{*}{ Mouse } & \multirow{2}{*}{$\begin{array}{l}\text { i.p. injection of } \\
\text { MG5 cells }\end{array}$} & \multicolumn{2}{|c|}{$\begin{array}{l}\text { i.a. injection of } \\
\text { peptide }\end{array}$} & \multicolumn{2}{|c|}{$\begin{array}{l}\text { Knee joint } \\
\text { swelling }\end{array}$} & \multicolumn{2}{|c|}{$\begin{array}{c}\text { Knee histology } \\
\text { score }\end{array}$} \\
\hline & & Left & Right & Left & Right & Left & Right \\
\hline 1 & none & G5 & Y15 & - & - & \pm & - \\
\hline 2 & none & G5 & Y15 & - & - & - & \pm \\
\hline 3 & none & G5 & Y15 & - & - & - & - \\
\hline 4 & none & G5 & Y15 & - & - & \pm & - \\
\hline 5 & none & G5 & Y15 & - & - & - & - \\
\hline 6 & none & G5 & Y15 & - & - & - & - \\
\hline 7 & $1 \times 10^{7}$ cells & G5 & medium & + & - & +++ & - \\
\hline 8 & $1 \times 10^{7}$ cells & G5 & medium & + & - & +++ & - \\
\hline 9 & $1 \times 10^{7}$ cells & G5 & Y15 & + & - & ++ & - \\
\hline 10 & $1 \times 10^{7}$ cells & G5 & Y15 & + & - & +++ & - \\
\hline 11 & $1 \times 10^{7}$ cells & G5 & Y15 & + & - & +++ & - \\
\hline
\end{tabular}

$1 \mathrm{ml}$ of serum-free medium, without (mice 1-6) or with (mice 7-11) $10^{7}$ peptide G5-specific T cells, was injected intraperitoneally into mice on day $0.1 \mathrm{~h}$ later, all left knees were injected intraarticularly with peptide G5 (10 $\mu \mathrm{g}$ in $10 \mu \mathrm{l}$ serum-free medium), whereas the right knee joint was injected with an equal amount of unrelated peptide Y15 in serumfree medium or with medium alone. The joint swelling and histopathology scores are as described in Methods. i.a., Intraarticular. 
presses an $\alpha \beta$-type $\mathrm{T}$ cell receptor with a preferential usage of $\mathrm{V} \beta 8$ gene (Table I). These features are often observed in studies of T cells involved in autoimmunity $(17,18)$. MG5 T cells injected into the peritoneal cavity induced acute arthritis in knee joints that had been injected intraarticularly with peptide G5 in serum-free culture medium, but not in joints that had been injected with serum-free medium alone or with serumfree medium plus an equal amount of an unrelated bovine link protein peptide (Y15) (Table V, Fig. 3, $c$ and $d$ ). Intraarticular injection of peptide G5 alone did not induce joint swelling and histologically defined arthritis (Fig. $3 \mathrm{~b}$ ), although a limited mononuclear cell infiltration in knee synovial tissue was occasionally observed (graded \pm ) with either peptide when injected alone (Table V).

\section{Discussion}

Our earlier studies linking cellular immunity to aggrecan, the major proteoglycan of cartilage, with development of arthritis and spondylitis in BALB/c mice $(3,4,7)$ raised the important question of the location of the arthritogenic epitope(s). Later, we showed that the isolated G1 globular domain of bovine ag- grecan, when depleted of $\mathrm{KS}$, induces a similar arthritis and spondylitis. We can therefore assume that an arthritogenic epitope(s) responsible for this arthritis is located in the G1 domain of aggrecan $(5,10)$. In this study, we show that there are two epitopes that are recognized by $\mathrm{T}$ cell lines specific to proteoglycan core protein or G1, located within residues 70-84 and 150-169 (Tables II and III). We show that adoptive transfer of T cells specific for peptide 70-84 (G5) into BALB/c mice leads to development of arthritis in knee joints, but only in those that have received an intraarticular injection of the same peptide (Table V, Fig. 3). Moreover, two T cell hybridomas generated from BALB/c mice with severe inflammatory arthritis-TH5 and TH14 - that recognize both human fetal and adult PG (10) were also found to respond exclusively to peptide 70-84. Hence, we have direct evidence to show that the peptide G5 (70-84) contains an arthritogenic epitope that is recognized by $\mathrm{T}$ cells and induces homing of these $\mathrm{T}$ cells to joints containing the peptide with induction of arthritis. Since these $\mathrm{T}$ cells cross-react with the homologous mouse sequence, despite a two-amino acid difference (Table III), release of sufficient mouse epitope from damaged articular cartilage could elicit a $\mathrm{T}$ cell response that can involve creation of intraarterial
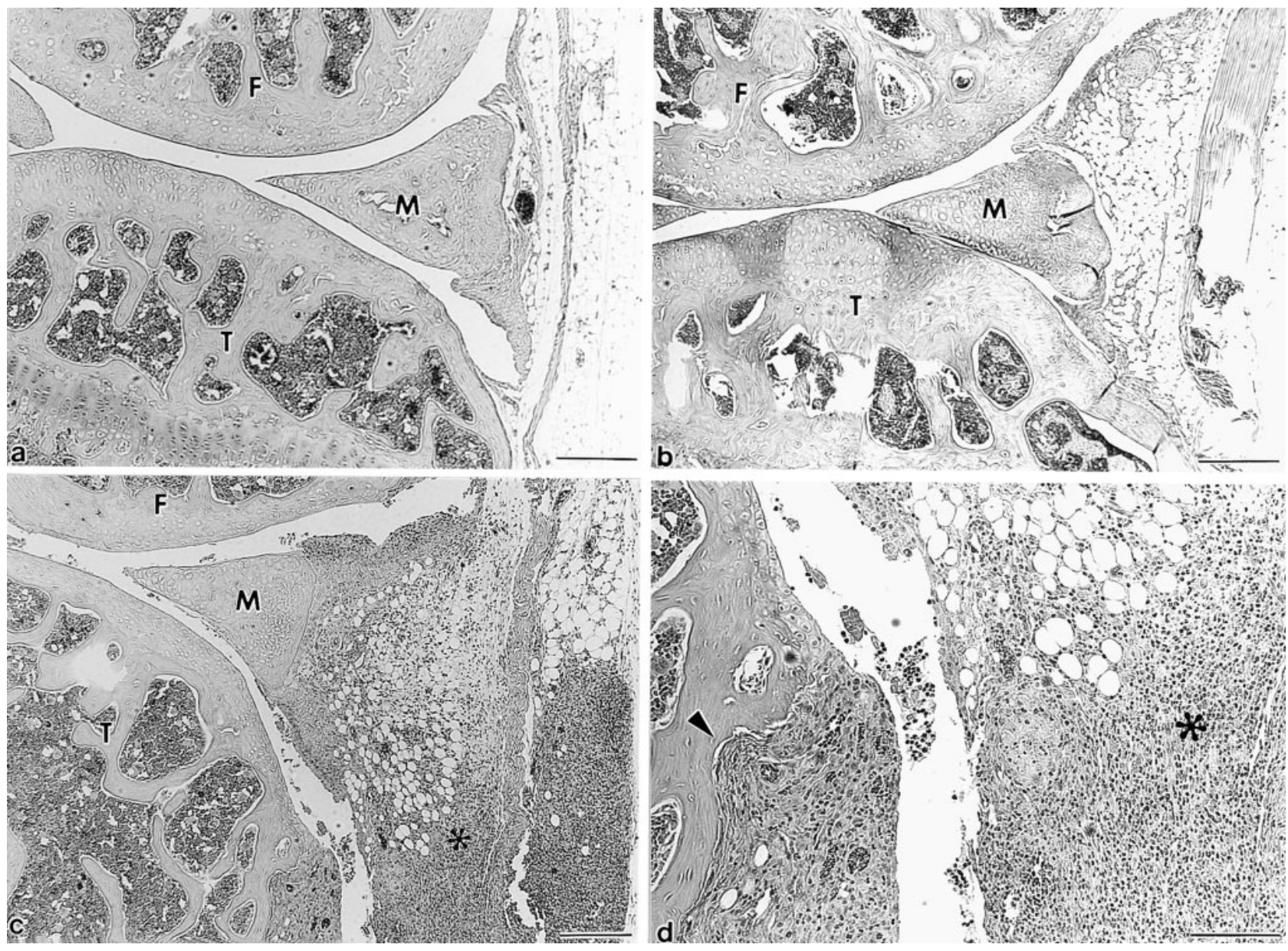

Figure 3. Histology of arthritis induced by arthritogenic T lymphocyte line (MG5). 6- $\mu \mathrm{m}$ sections were stained with hematoxylin and eosin to show nonarthritic controls: (a) mouse number 1, left knee injected with peptide G5 but no T cells intraperitoneally (i.p.); (b), mouse 9 right knee injected with unrelated peptide Y15 and with T cells i.p.; $(c)$ arthritic mouse 9, left knee injected with peptide G5 and T cells i.p.; $(d)$ enlarged view of $c$. For details of mouse number and experimental design see Table V. F, femur; $T$, tibia; $M$, meniscus. *Common regions in $c$ and $d$. Arrow shows erosive bone destruction. A pronounced capsular and synovial infiltration of mononuclear cells with synovitis, and bone erosion can be seen in $c$ and $d$ where T cell line MG5 has homed to its epitope injected intraarticularly. $(a-c)$ Bars $=200 \mu \mathrm{m} ;(d)$ bars $=100 \mu \mathrm{m}$. 
inflammation via a molecular mimicry mechanism (19). Moreover, these observations suggest that release of epitope(s) from articular cartilages, which is recognized by specific $\mathrm{T}$ cells, can lead to their homing to these joints where the epitope(s) is excessively released, which may help explain the intraarticular inflammation of rheumatoid arthritis.

Peptide 150-169 is a subdominant T cell epitope compared with epitope 70-84. However, T cell lines that are produced against PG or G1, either with or without KS depletion, all consistently show a strong response to this peptide. Furthermore, peptide 150-169 is located within an absolutely conserved region of the aggrecan core protein in human, bovine, rat, and mouse G1 (20-23). Together, these data provide direct evidence to suggest that challenge to the host immune system with a structural protein from another species is capable of initiating an autoreactive $\mathrm{T}$ cell response. We recently discovered that PBLs of rheumatoid arthritis and juvenile rheumatoid arthritis patients often respond to G1, and that G1-specific T cells can be found in the peripheral blood and synovial fluid of rheumatoid arthritis patients, including $\mathrm{T}$ cells recognizing epitope 150-169 (Y. Zhang and A.R. Poole, unpublished data). Therefore, peptide 150-169 may also contain a potential arthritogenic T cell epitope.

Our previous studies have shown that KS attachment to G1 can inhibit $\mathrm{T}$ cell recognition since deletion of KS enhances the $\mathrm{T}$ cell proliferative response $(5,10)$. We show in this study that the enhancement of T cell immunity by KS depletion is not an uncommon event. T cells specific for PG, G1, G1-KS, or the predominant epitope 70-84 all show an enhanced response to
KS-depleted G1 protein regardless of which TCR V $\beta$ gene they use (Table II, Fig. 1). It is also notable that selection of the predominant $\mathrm{T}$ cell epitope from the $\mathrm{T}$ cell receptor repertoire is not determined by whether it is the chondroitin sulfate or keratan sulfate side chains that are removed (Table II, Fig. 1). The mechanism involved in enhancing the antigen-specific T cell response, as we suggested (5), may be associated with increased binding to and endocytosis by antigen-presenting cells.

Besides carbohydrates inhibiting epitope recognition by $\mathrm{T}$ cells (24), B cell recognition can also be hindered (25). One purpose of this study was to identify the regions in aggrecan G1 protein recognized by B cells, and to see whether KS can also inhibit B cell responses. Without $\mathrm{KS}$ chains, the B cellreactive regions were more than 3.7 times larger than those with KS chains. In other words, the majority of G1 epitopes were protected by KS from B cell recognition. Removing KS has two effects on the B cell response: one is quantitative by enhancing antibody-binding activity, and the other is qualitative by exposing more $\mathrm{B}$ cell regions. This result suggests that the presence of KS on G1 masks potential B cell epitope regions from recognition, and prevents them from inducing antibodies to the core protein. Therefore, removing KS chains not only plays a role in enhancing autoreactive $\mathrm{T}$ cell reactivity, but may also be involved in the pathogenesis of arthritis by enhancing $\mathrm{B}$ cell immunity.

In bovine cartilage, $\mathrm{O}$ - or $\mathrm{N}$-linked $\mathrm{KS}$ chains can occur within each of the disulfide-bonded loops (at residues 42, 220, and 314) of the G1 globular domain as well as at residues 352, $355,357,368$, and 370 near the aggrecanase cleavage site (argi-
A

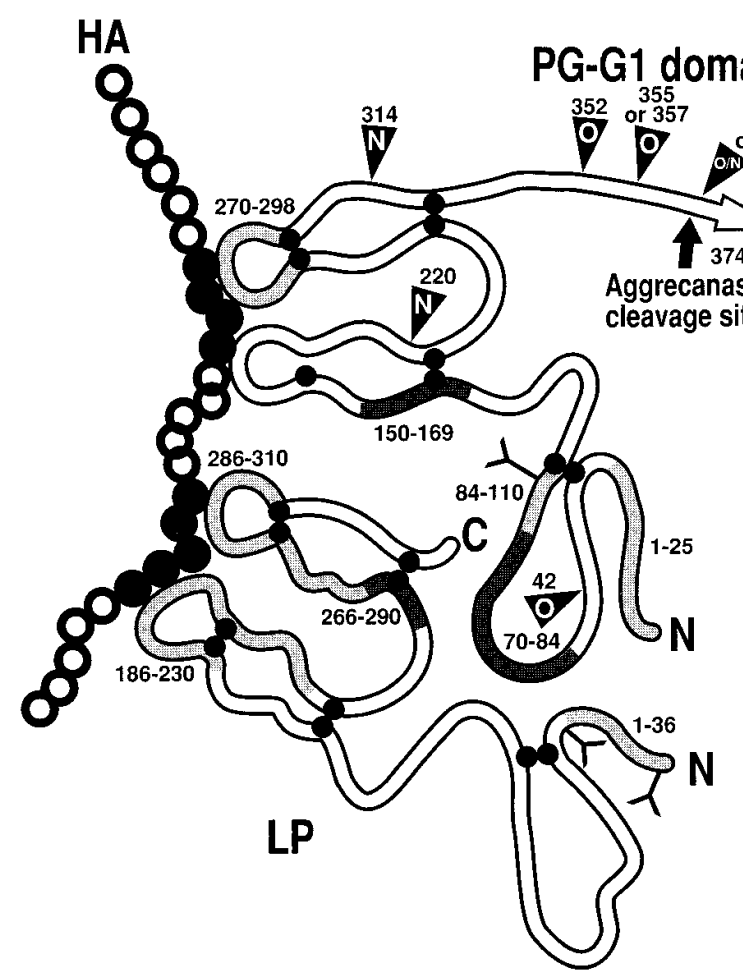

B

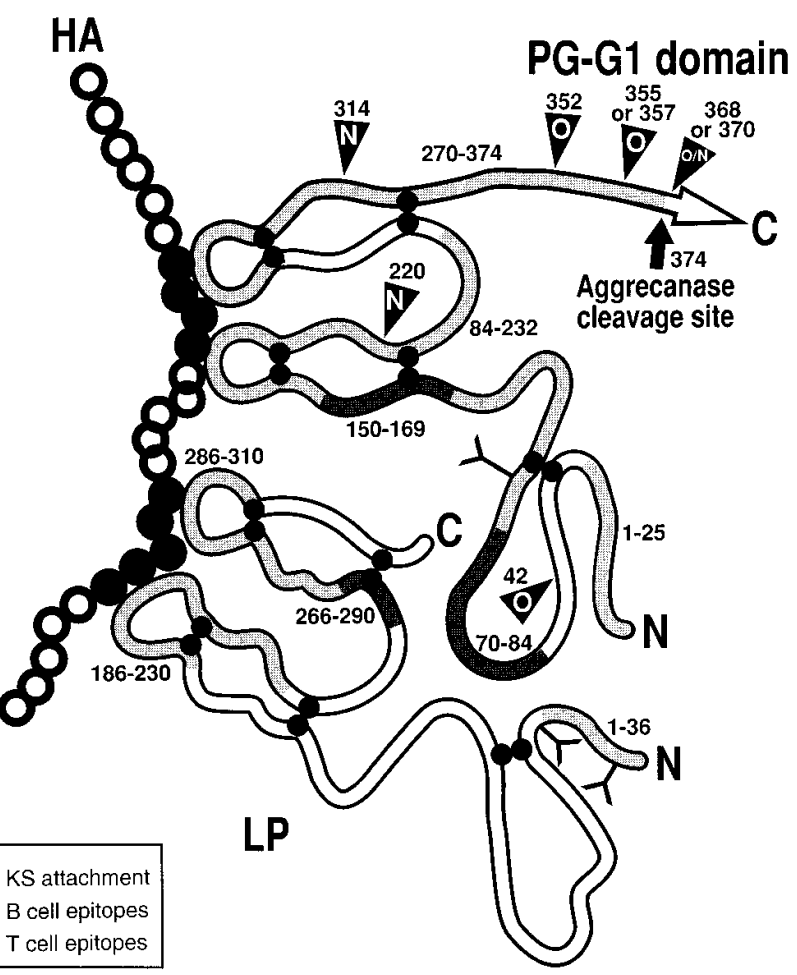

Figure 4. Diagram of B cell epitope distribution on bovine aggrecan G1 protein and link protein (30). For a detailed explanation, see Discussion. Both $\mathrm{O}$ and $\mathrm{N}$ linkages of $\mathrm{KS}$ are indicated at the residues shown. The positions of oligosaccharides $(Y)$ and the binding sites for attachment to hyaluronan $(H A)$ are also shown. Epitopes in G1 recognized by T and B cells are shown $(A)$ before and $(B)$ after removal of KS. 
nine residue 374; Fig. 4; reference 26). At present, there is no direct way to determine which of these $\mathrm{KS}$ chains is important in inhibiting the B cell response. However, analyzing the relationship between the distribution of the KS chain and the antibody-reactive regions in G1 may provide critical clues. When animals were immunized with native G1, their antibodies recognized three clustered regions in G1 within residues 1-25, 84110, and 276-297 (Fig. $2 A$ ), indicating that recognition of these regions is not masked by KS chains. It seems that the O-linked KS chain at residue 42 in the immunoglobulin-like loop A contributes less protection, because two immediately adjacent regions (1-25 and 84-110) are susceptible to antibody reactivity (Fig. $2 A$ ). Moreover, after removal of KS, the antibody-reactive regions remain unchanged (Fig. $2 B$ ), though it may also be due to lack of O-linked $\mathrm{KS}$ at residue 42 in our calf G1 preparations (26).

Link protein is known to have structural similarities with G1, but it has no KS chain. There are two regions containing tandem repeat sequences in both molecules B and $\mathrm{B}^{\prime}$, which are involved in binding with $\mathrm{HA}(27,28)$. G1, especially the B and $\mathrm{B}^{\prime}$ regions, are homologous with link protein $(23,29)$, and immune cross-reactivity between G1 and link protein is not uncommon (10). Interestingly, native G1 and link protein share one $\mathrm{B}$ cell reactive region located in the $\mathrm{B}^{\prime}$ region covering the entire small loop within residues 289-310 for link and 278-299 for G1 protein (Fig. 4 A). LP loop B contains a highly immunogenic region for B cells (residues 206-237). However, no corresponding B cell-reactive region(s) has been identified in loop B of G1. In G1, loops B and B' each possess an N-linked $\mathrm{KS}$ attachment site located at corresponding position (residue 220 for loop B and 314 for loop B'). N-linked KS (at residue 220) may provide more protection to loop $B$ regions than that at residue 314 on the B' loop, since KS 314 cannot provide protection from antibody recognition of region 278-299 in loop $\mathrm{B}^{\prime}$. Moreover, after depletion of KS chains, antibody-accessible regions cover the full length of the $\mathrm{B}$ loop, whereas only part of loop B' is accessible to antibodies. The present data indicate that the $\mathrm{N}$-linked KS chain at residue 220 in loop B may have a greater protective effect than the other KS chains. We have previously shown that the G1 domain can be detected in synovial fluids of patients with arthritis (30). In chronic rheumatoid arthritis, there is likely a similar enrichment of G1 in cartilage as is also observed in synovial fluid $(30,31)$. It is well known that KS content increases with age (9) and decreases in arthritis (32). An increase of KS with age may protect individuals from arthritis, while the loss of KS in arthritic patients might favor immune responses to the G1 domain. The presence of KS can be viewed as a protective element that downregulates immunity to the $\mathrm{G} 1$ domain.

\section{Acknowledgments}

We thank Isabelle Pidoux-Perera for excellent technical assistance and Jane Wishart for the artwork.

This study was funded by the Shriners of North America (to A.R. Poole and Y. Zhang), the Riva Foundation (to A.R. Poole), and U.S. Public Health Service grant AR34614.

\section{References}

1. Golds, A.A., I.B.M. Stephen, J.M. Esdaile, H. Strawczynski, and A.R. Poole. 1983. Lymphocyte transformation to connective tissue antigens in adult and juvenile rheumatoid arthritis, osteoarthritis, ankylosing spondylitis, systemic lupus erythematosus and a nonarthritic control population. Cell. Immunol. 82:196-209.

2. Mikecz, K., T.T. Glant, M. Baron, and A.R. Poole. 1988. Isolation of proteoglycan-specific $\mathrm{T}$ lymphocytes from patients with ankylosing spondylitis. Cell. Immunol. 112:55-63.

3. Glant, T.T., K. Mikecz, A. Arzoumanian, and A.R. Poole. 1987. Proteoglycan induced arthritis in BALB/c mice.Clinical features and histopathology. Arthritis Rheum. 30:201-212.

4. Mikecz, K., T.T. Glant, and A.R. Poole. 1987. Immunity to cartilage proteoglycans in $\mathrm{BALB} / \mathrm{c}$ mice with progressive polyarthritis and ankylosing spondylitis induced by injection of human cartilage proteoglycan. Arthritis Rheum. 30:306-318.

5. Leroux, J.-Y., A. Guerassimov, A. Cartman, N. Delaunay, C. Webber, L.C Rosenberg, S. Banerjee, and A.R. Poole. 1996. Immunity to the G1 globular domain of the cartilage proteoglycan aggrecan can induce inflammatory erosive polyarthritis and spondylitis in BALB/c mice but immunity to $\mathrm{G} 1$ is inhibited by covalently bond keratan sulfate in vitro and in vivo. J. Clin. Invest. 97:621-632.

6. Mikecz, K., T.T. Glant, E. Buzas, and A.R. Poole. 1990. Proteoglycaninduced polyarthritis and spondylitis adoptively transferred to naive (nonimmunized) BALB/c mice. Arthritis Rheum. 33:866-876.

7. Banerjee, S., C. Webber, and A.R. Poole. 1992. The induction of arthritis in mice by the cartilage proteoglycan aggrecan: Roles of CD4+ and CD8+ T cells. Cell. Immunol. 144:347-357.

8. Glant, T.T., K. Mikecz, P.J. Roughley, E. Buzàs, and A.R. Poole. 1986. Age-related changes in protein-related epitopes of human articular cartilage proteoglycans. Biochem. J. 236:71-75.

9. Roughley, P.J., and R.T. White. 1980. Age related changes in the structures of the proteoglycan subunits from human articular cartilage. J. Biol. Chem. 225:217-224.

10. Leroux, J.Y., A.R. Poole, C. Webber, V. Vipparti, H.K. Choi, L.C. Rosenberg, and S. Banerjee. 1992. Characterization of proteoglycan-reactive T cell line and hybridomas from mice with proteoglycan-induced arthritis. J. Immunol. 148:2090-2096.

11. Tang, L.H., L.A. Rosenberg, A. Reiner, and A.R. Poole. 1979. Proteoglycan from bovine nasal cartilage. Properties of a soluble form of link protein. J. Biol. Chem. 254:10523-10531.

12. Oike, Y., K. Kimata, T. Shinomura, K. Nakazawa, and S. Suzuki. 1980. Structural analysis of chick-embryo cartilage proteoglycan by selective degradation with chondroitin lyases (chondroitinases) and endo- $\beta$-D-galactosidase (keratanase). Biochem. J. 191:193-207.

13. Zhang, Y., T. Barkas, M. Juillerat, B. Schwendimann, and H. Wekerle. 1988. T cell epitopes in experimental autoimmune myasthenia gravis of the rat: Strain-specific epitopes and cross-reaction between two distinct segments of the alpha chain of the nicotinic acetylcholine receptor (Torpedo californica). Eur. J. Immunol. 18:551-557.

14. Ben-Nun, A., H. Wekerle, and I.R. Cohen. 1981. The rapid isolation of clonable antigen-specific T lymphocyte lines capable of mediating autoimmune encephalomyelitis. Eur. J. Immunol. 11:195.

15. Kappler, J.W., B. Skidmore, J. White, and P. Marrack. 1981. Antigeninducible $\mathrm{H}-2$ restricted interleukin-2 producing $\mathrm{T}$ cell hybridomas. Lack of independent antigen and H-2 recognition. J. Exp. Med. 153:1198-1214.

16. Mosmann, T.R., H. Cherwinski, M.W. Bond, M.A. Giedlin, and R.L. Coffman. 1986. Two types of murine helper T clone. I. Definition according to profiles of lymphokine activities and secreted proteins. J. Immunol. 136:2348-2357.

17. Weinberg, A.D., B. Celnik, M. Vainiene, A.C. Buenafe, A.A. Vandenbark, and H. Offner. 1994. The effect of TCR V beta 8 peptide protection and therapy on $\mathrm{T}$ cell populations isolated from the spinal cord of Lewis rats with experimental autoimmune encephalomyelitis. J. Neuroimmunol. 49:162-170.

18. Kalman, B., R.L. Knobler, and F.D. Lublin. 1993. T cell receptor V beta gene uternization in myelin basic protein-specific clones from CXJ1 recombinant inbred mice. J. Neuroimmunol. 43:191-194.

19. Fujinami, R.S., and M.B.A. Oldstone. 1985. Amino acid homology between the encephalitogenic site of myelin basic protein and virus: mechanism for autoimmunity. Science. 230:1043-1045.

20. Doege, K.J., M. Sasaki, T. Kimura, and Y. Yamada. 1991. Complete coding sequence and deduced primary structure of the human cartilage large aggregating proteoglycan, aggrecan. Human-specific repeats, and additional alternatively spliced forms. J. Biol. Chem. 266:894-902.

21. Rosenberg, L.C., H.U. Choi, L.H. Tang, T.L. Johnson, S. Pal, C. Webber, A. Reiner, and A.R. Poole. 1985. Isolation of dermatan sulfate proteoglycans from mature bovine articular cartilage. J. Biol. Chem. 260:6304-6313.

22. Walcz, E., F. Deak, P. Erhardt, S.N. Coulter, C. Fulop, P. Horvath, K.J. Doege, and T.T. Glant. 1994. Complete coding sequence, deduced primary structure, chromosomal localization, and structural analysis of murine aggrecan. Genomics. 22:364-371.

23. Doege, K., M. Sasaki, E. Horigan, J.R. Hassell and Y. Yamada. 1987. Complete primary structure of the rat cartilage proteoglycan core protein deduced from cDNA clones. J. Biol. Chem. 262:17757-17767.

24. Ishioka, G.Y., A.G. Lamond, D. Thomson, N. Bulbow, F.C.A. Gaeta, A. Sette, and H.M. Grey. 1992. MHC interaction and T cell recognition of carbohydrates and glycopeptides. J. Immunol. 148:2446-2451. 
25. Fosang, A.J., and T.E. Hardingham. 1991. 1-C-6 epitope in cartilage proteoglycan G2 domain is masked by keratan sulfate. Biochem. J. 273:369-373.

26. Barry, F.P., L.C. Rosenberg, J.U. Gaw, T.J. Koob, and P.J. Neame. 1995. N-and O-linked keratan sulfate on the hyaluronan binding region of aggrecan from mature and immature bovine cartilage. J. Biol. Chem. 270:2051620524.

27. Yang, B., B. Yang, R. Savani, and E. Turley. 1994. Identification of a common hyaluronan binding motif in the hyaluronan binding protein RHAMM, CD44 and link protein. EMBO (Eur. Mol. Biol. Organ) J. 13:286-296.

28. Goetinck, P.F., N.S. Stirpe, P.A. Tsonis, and D. Carlone. 1987. The tandemly repeated sequences of cartilage link protein contain the site for interaction with hyaluronic acid. J. Cell. Biol. 105:2403-2411.
29. Neame, P.J., E. Christner, and J.R. Baker. 1987. Cartilage proteoglycan aggregates. The link protein and proteoglycan amino-terminal globular domains have similar structures. J. Biol. Chem. 262:17768-17778.

30. Witter, J., P.J. Roughley, C. Webber, N. Roberts, E. Keystone, and A.R. Poole. 1987. The immunologic detection and characterization of cartilage proteoglycan degradation products in synovial fluids of patients with arthritis. $A r$ thritis Rheum. 30:519-529.

31. Saxne, T., and D. Heinegärd. 1992. Synovial fluid analysis of two groups of proteoglycan epitopes distinguishes early and late cartilage lesions. Arthritis Rheum. 35:385-390.

32. Poole, A.R. 1986. Changes in the collagen and proteoglycan of articular cartilage in arthritis. Rheumatology. 10:316-371. 